\title{
Socio-cultural context of older preschool children's initiative development on the basis of volunteer activities
}

\author{
Nina Tatarintseva ${ }^{1, *}$ and Marina Zelinskaya ${ }^{1}$ \\ ${ }^{1}$ Southern Federal University, Rostov-on-don, 344006, Russia
}

\begin{abstract}
In world modernization context modern challenges in education are formed. Federal normative legal documents reflect social demand to create conditions for development of an initiative person with socially active and civil position, capable of successful response to modern society requirements. Initial stages of solving this problem are in the senior preschool age, as synesthetic period of child's personality socialization and older preschoolers' socio-cultural personality development. The federal state educational standard for preschool education directs teachers to create social situation for children's initiative development through pedagogical conditions establishment in socio-cultural context. Analysis of theoretical methodological works and existing practices reveals volunteering pedagogical potential, tendency to involve older preschoolers into it. The paper examines theoretical, methodological foundations, psychological and pedagogical conditions of children's initiative development process on volunteer activities basis. Research purpose is to scientifically substantiate, develop and test psychological, pedagogical conditions for older preschool children's initiative development. Research methods are comparative, complex system analysis of scientific research in pedagogical, sociological, philosophical works. Theoretical and methodological foundations and complex of psychological and pedagogical conditions for older preschool children's initiative development based on volunteer activities are established as structural and functional model, "Preschool Volunteer" program and initiative developing technology for older preschool children. The author's concepts of "older preschool children initiative" and "volunteer activity of older preschool children" are formed. The socio-cultural context of initiative development involves volunteer practices with children. The research results can be used in lecture course preparation, professional programs for teachers and parents competence development in preschool educational organizations.
\end{abstract}

\section{Introduction}

An important problem of modern preschool education is the rethinking of the goals and objectives of the upbringing process, the search for new approaches that contribute to positive socialization and individualization of the personality, the development of the preschool

\footnotetext{
* Corresponding author: nina tatarinceva@mail.ru
} 
children's personality activity in accordance with their gender, age and individual characteristics. The Federal State Educational Standard of preschool education establishes one of the main principles of a modern preschool organization activity, which is supporting children's initiative in a variety of activities. If previous studies were devoted to proving the possibility of developing initiative at a given age, now there is a search for ways to develop this quality in preschool age, awareness of the necessary psychological and pedagogical conditions when organizing various types of activity.

The relevance of this research is determined at the socio-pedagogical level as the increasing social demands to the level of initiative of preschoolers; at the scientific and theoretical level as the need to create theoretical foundations for the development of initiative in older preschoolers' volunteering; at the methodological and technological level as the lack of an effective technological apparatus for the development of preschoolers' initiative while implementing volunteer activities.

The study of solving of developing initiative in preschool age problem is presented in the scientific works of E. E. Kravtsova, L. F. Obukhova, D. I. Feldstein, S. A. Kozlov and others. The phenomenon is considered in various types of activities. The solution to the issue of developing initiative in the aspect of organizing volunteer activities is associated with the works of L.V. Bolotova, I.N. Grigoriev, V.N. Melnikova, Y.V. Parshina, E.A. Romanenko, O. I. Kholina, and others.

On the federal level this problem is legalized in such documents as the Federal Law "On Education in the Russian Federation", the Federal State Educational Standard of Preschool Education. "

The importance of the issue of developing the preschool children's initiative is noted in the Federal State Educational Standard of Preschool Education as one of the psychological and pedagogical conditions requirements for the implementation of the main educational program, such as support of the initiative and independence of children in specific activities, target guidelines of preschool education as social and normative age characteristics of the child's possible achievements.

Of particular importance for the development of initiative is senior preschool age, by the end of which "initiative manifests itself in a more differentiated and diverse manner," and children develop independence in various types of activity (L.V. Artemova, L. I. Bozhovich, M.V. Krulekht, G B. Monina, V. S. Mukhina, N. N. Podyakov, D. I. Feldshtein and others).

Studying the history of the issue raised in the paper shows that the concept of "initiative" has historically changed depending on social norms and ethical ideas. It is considered by scientists from various scientific fields - philosophy, sociology, psychology, pedagogy. The study of the theoretical aspects of the development of individual initiative in psychological and pedagogical research and the description of practical experience takes place within the framework of the analytical (S.L. Rubinstein, K.A. Abulkhanova-Slavskaya, D.B. Bogoyavlenskaya) and systemic approaches (A.I. Krupnov, A.S. Zharikova, T.B. Popova and others).

Analysis of scientific works showed that in modern research, revealing various means and conditions for the development of individual initiative, scientists consider socio-cultural activities (T.S. Borisova, E.N. Dan'kova), educational and cognitive activities (A.A. Klepikova, T.D. Savenkova.), artistic and creative activity (I.Y. Kosheleva, A.S. Zharikova), project activities (E.V. Oparina, M.R. Pogodaeva), organization of a healthy lifestyle (V. Y. Krotova, T. Y. Burlakova), and virtual space (V.V. Gura, E.D. Nevesenko).

Thus, the importance of developing the initiative of senior preschool age children problem is dictated by the society need for socially active (initiative) members who are able to make responsible decisions and participate in socially significant activities for the benefit of others, by the requirements of the Federal State Educational Standard of Preschool Education focused on organizing and finding effective forms of building pedagogical preschool 
education process aimed at developing independence, initiative, creativity in preschoolers, fostering patriotism and civic consciousness, as well as on scientific research in the field of pedagogy and psychology.

Among the possible factors in the development of the initiative of older preschoolers, the organization of children's volunteer activities can be considered.

The effectiveness of volunteer activities in various aspects has been proven by such scientists in the following aspects of the problem: volunteering as a social phenomenon (M. N. Balanyan, 2015), the managerial aspect (M. V. Pevnaya, 2016), economic employment of volunteers in Russia (A. V. Trokhina, 2012), moral development in volunteering (Yu.V.Parshina, 2011), preparation for volunteering (N.V. Makovei, 2006), development of professional qualities in volunteering (T. B. Matsyuk, 2019) methodological foundations of volunteering in the structure of civil society (D. A. Gedunova, 2017 and others).

However, most of the scientific research works on volunteer activity are associated with students of higher educational institutions and consider it as an aspect of vocational training, while there is very little research on volunteer activity of preschoolers.

Understanding the relevance of the study, analysis of research results and modern practice of developing the initiative of older preschool children has made it possible to formulate the problem of our research: the theoretical and methodological foundations and pedagogical conditions of the process of developing children's initiative on the basis of volunteer activity.

The purpose of the research is to scientifically substantiate, develop and test psychological and pedagogical conditions for the development of initiative in older preschool children on the basis of volunteer activities.

One of the pedagogical conditions for the effectiveness of the process of developing initiative in older preschool children on the basis of volunteer activity is to determine the theoretical and methodological foundations of developing initiative process in older preschool children, during which the socio-cultural context of the development of initiative in older preschool children is identified.

\section{Materials and methods}

To achieve the goal of the research, the following research methods and techniques were used: organizational (comparative, complex, systemic analysis, etc.); empirical (observation, psychological and pedagogical experiment, testing, etc.); interpretive (method of logical analysis, statistical methods). The social-functional model, the partial program and the technology for the development of initiative in older preschool children were tested on the basis of volunteer activities.

The analysis of the theoretical and methodological foundations and practices made it possible to put forward the assumption that the process of developing the initiative of older preschoolers on the basis of volunteer activity will be effective under the following psychological and pedagogical conditions:

- theoretical and methodological foundations of the process of developing initiative in older preschool children in volunteer activity have been determined;

- structural and functional model of the process of developing the initiative of senior preschool children has been tested, including the following components: diagnostic goalsetting; organizational and content planning; design and implementation, reflection and correction;

- a partial program, socio-pedagogical, value content providing the process of developing initiative of preschoolers in volunteer activities has been implemented;

- technology for the development of initiative representing the integration of various types of volunteer activities ("volunteering as a co-existence", "family volunteering", "virtual (online) volunteering", "volunteering as leisure", etc.) has been implemented. 
The study involved 116 children aged 5 to 7 years. The experimental study was organized on the basis of "Kindergarten No. 50" and "Kindergarten No. 77".

At the problem-search stage, a theoretical and methodological analysis of philosophical, psychological, pedagogical and methodological works was carried out, psychological and pedagogical conditions for the development of initiative in volunteering were developed.

At the next theoretical and modeling stage, the development of a structural and functional model, the content of a partial program and technology for the development of initiative of preschoolers in volunteer activities was carried out.

\section{Results}

The potential of volunteer activity in the process of developing the initiative of senior preschool children has been investigated.

Criteria, indicators, levels (motivational-value, information-cognitive, emotionalvolitional, regulatory-activity) of the development of initiative in senior preschool children are identified and described.

The concepts of "initiative of senior preschool children" have been clarified in "Volunteer activities of children in a preschool educational organization."

Significant differences have been found in the level of development of initiative in senior preschool children before and after the introduction of the model, partial program and technology for the development of initiative in senior preschool children based on volunteer activities.

A model for the development of initiative in older preschool children has been scientifically substantiated and developed on the basis of volunteer activities.

A partial program "Junior Volunteers" has been developed and tested, aimed at developing the initiative of preschoolers on the basis of volunteer assistance.

On the basis of the results obtained, the study substantiated the patterns of the development of initiative in older preschool children on the basis of volunteer activities.

The effectiveness of the developed model, partial program, technology for the development of initiative in older preschool children on the basis of volunteer activity has been experimentally proven.

\section{Discussion}

One of the pedagogical conditions for the effectiveness of developing initiative process in older preschool children on the basis of volunteer activity is to determine the theoretical and methodological foundations of this process during which the socio-cultural context of the development of initiative is identified.

For the purposes of our research, the working definition of the concept of "socio-cultural" is a synthesis of methods, sources, means, and values of culture and socialization, which are used in solving social and cultural problems.

A. V. Mudrik gives the following definition of the latter as "cognitive, moral, ethic, valuesemantic tasks that are specific for each age stage in a particular historical society. They are determined by the society as a whole, by the regional and immediate environment of a person" [8].

The Federal State Educational Standard of Preschool Education determines (as one of the main tasks) the need for the implementation of the educational process on the basis of sociocultural values and the formation of a socio-cultural environment in accordance with the age peculiarities of preschoolers [15]. 
A. A. Verbitsky defines the "context" concept as "a system of internal and external conditions of life and human activity, influencing the process and results of perception, a person's understanding and transformation a specific situation of action and deed. Accordingly, the internal context is individual psychological characteristics, knowledge and experience of a person, the external context is information, subject, socio-cultural, spacetime and other characteristics of the situation in which he acts" [3]. So, the socio-cultural context is the reflection of these concepts in various kinds of activities.

Based on the research of N. I. Lapin, for the purposes of our research, we consider the socio-cultural context of the development of older preschool children's initiative as a unity of culture and sociality.

By the culture Lapin N. I. means "a set of methods and results of a child's activity (material and spiritual - ideas, values, norms, patterns, etc.)" and by sociality he means "a set of relationships between social subjects (parents, volunteers, veterans, social partners) formed in the process of activity" ... [6].

As discussed by Y.L. Belyakova "The specificity of the socio-cultural approach consists in the integration of three dimensions of human existence (the type of relationship between a person and society, the nature of culture, the type of sociality) precisely as fundamental, each of which is not reduced to others and is not derived from them, but at the same time they are all interconnected and affect each other as the most important components of human communities" [2].

Analysis of the results of research and modern practice of preschool education made it possible to reveal the tendency of preschool education in the all-round expansion of opportunities and conditions for the development of a child in the process of active assimilation to socio-cultural experience.

Volunteering is one of the new activities in the children's environment and it has already shown its viability and effectiveness, it is a pedagogical technology in which children become proactive and independent in choosing the ways to express their interests, which is one of the main requirements of the Federal State Educational Standard of Preschool Education.

Thus, the socio-cultural context of the development of older preschool children' initiative is to consider children's volunteering as one of the forms of the educational process; pedagogical technology of socialization; as a sphere of formation and development of the basic qualities of the personality and culture of the child. An older preschooler, being a subject of transformations in volunteer activities, gains social and cultural experience, shows initiative, learns to interact with social partners of different cultures, realizes the need for communication and the right to participate in social and creative leisure.

Since the detailed research procedures are long-term and laborious, theoretical and empirical research is presented.

As a result of studying the content side of the process of older preschool children' developing initiative on the basis of volunteer activities, the main concepts that are significant for our study are identified. Key points of view on this problem are presented below.

Table 1. Basic approaches to the study of initiative.

\begin{tabular}{|l|l|l|}
\hline \multicolumn{2}{|c|}{ Period } & \\
\hline \multicolumn{2}{|c|}{ Personalities } & \\
\hline In pedagogy researching the signs of initiative: \\
\hline $\begin{array}{l}\text { Ushinsky } \\
(1824-1870)\end{array}$ & D. & $\begin{array}{l}\text { emphasized "the need to develop and support originality as a desire to show a } \\
\text { personal initiative in one's activity, considering initiative as a personal property } \\
\text { and warned the educator against suppressing it" [16]. }\end{array}$ \\
\hline $\begin{array}{l}\text { Tolstoy L. } \\
(1828-1910)\end{array}$ & N. & $\begin{array}{l}\text { "called for a new type of relationship between teachers and students, which } \\
\text { would eliminate coercion, defend the idea of personality development as central, } \\
\text { would encourage his students to be independent, which in turn would lead to the } \\
\text { development their activity, initiative and creativity" [16]. }\end{array}$ \\
\hline
\end{tabular}




\begin{tabular}{|c|c|}
\hline \multicolumn{2}{|c|}{$\begin{array}{l}\text { In post-revolutionary Russian pedagogy (new pedagogy), ideas of upbringing a person of the } \\
\text { new era. }\end{array}$} \\
\hline \begin{tabular}{ll|} 
Shatsky & S.T. \\
$(1878-1934)$ & \\
\end{tabular} & $\begin{array}{l}\text { argued that both initiative and independence occurred when studying various } \\
\text { disciplines and participating in real life events [17]. }\end{array}$ \\
\hline $\begin{array}{l}\text { Makarenko A. S. } \\
(1888-1939)\end{array}$ & $\begin{array}{l}\text { In "Lectures for Parents" he wrote that "initiative is a product of vigorous } \\
\text { activity" [7]. }\end{array}$ \\
\hline \multicolumn{2}{|c|}{ Definition of the concept of "initiative" by representatives of Russian pedagogical science } \\
\hline $\begin{array}{l}\text { Abulkhanova- } \\
\text { Slavskaya K.A. }\end{array}$ & $\begin{array}{l}\text { "The initiative is an outstripping external requirements or counter-free activity } \\
\text { of the subject, which is then realized in the intellectual or practical spheres" [1]. }\end{array}$ \\
\hline Krupnov A.I. & $\begin{array}{l}\text { "Initiative is a property that ensures the process of initiation and its completion, } \\
\text { which characterizes the urge to new, to outstrip the available stimulation" [5]. }\end{array}$ \\
\hline $\begin{array}{l}\text { Shukhardina S.B., } \\
\text { Svyatseva A.V. }\end{array}$ & $\begin{array}{l}\text { Initiative - an integrative quality of a person, characterized by motivational } \\
\text { readiness to perform one or another activity, certain knowledge (ideas) about the } \\
\text { course of its implementation, corresponding to both reproductive and productive } \\
\text { skills, as well as a conscious attitude to the goal and result of the activity. [12] }\end{array}$ \\
\hline
\end{tabular}

The analysis shows that researchers consider initiative as a personality trait, which is of an integrative character, and share it with the concept of "initiative".

Describing initiative of senior preschool children we mean an integrative quality that manifests itself in the internal readiness of an individual for socially activity, including the following components:

- motivational-value (motive as an incentive force, depends on beliefs, the level of development of value-semantic spheres, etc.);

- informational and cognitive (knowledge as information is associated with a person's ability to foresee and quickly find new solutions);

- emotional-strong-willed (internal motivation, expressed in the ability of a person to take initiative, etc.);

- regulatory activity (comprehension of one's own actions, self-knowledge, desire to actively act, etc.)

Table 2. Definition of the concept "volunteer activity".

\begin{tabular}{|l|l|}
\hline \multicolumn{1}{|c|}{ Personalities } & \multicolumn{1}{c|}{ Content } \\
\hline $\begin{array}{l}\text { D.N. Ushakov's } \\
\text { explanatory } \\
\text { dictionary. }\end{array}$ & $\begin{array}{l}\text { "volunteer (from the French. Volontaire) - entered the military service at will, } \\
\text { volunteer" [14]. }\end{array}$ \\
\hline Galman S. V. & "volunteering is the basis of human meaning formation" [4]. \\
\hline $\begin{array}{l}\text { "Modern } \\
\text { Encyclopedia of } \\
\text { Social Work" } \\
(2008)\end{array}$ & $\begin{array}{l}\text { "volunteering is any kind of activity aimed at helping people (individual, group, } \\
\text { community) who are not close relatives of volunteers; implementation of } \\
\text { socially significant projects; environmental protection" [13]. }\end{array}$ \\
\hline Pavlenok P.D. & $\begin{array}{l}\text { "volunteer activity is a voluntary type of activity carried out in accordance with } \\
\text { the need of conscience" [9]. }\end{array}$ \\
\hline Parshina Y. V. & $\begin{array}{l}\text { "volunteering is" a special type of activity that is significant for the socialization } \\
\text { of an individual in conditions when it is necessary to raise the spirituality of } \\
\text { society" [10]. }\end{array}$ \\
\hline
\end{tabular}

Thus, the conceptual analysis allows us to consider volunteer activity as a condition for the development of older preschool children' initiative.

As part of our study, scientific works have been considered, with the emphasis on research of the psychological and pedagogical component of this phenomenon (Yu.V. Parshina, L.E. Sikorskaya, M.I. Lyashenko, M.I. Vasilkovskaya, T.B. Matsyuk, N.V. Makovei, P.V. Rodionov and others.)

Among foreign authors studying the phenomenon of volunteering are K. Biederman, A. A. Schlichter, H. Anhaier, L. Salamon. 
Pevnaya M. I. in her research work refers to the works of American researchers H. Anheyer, L. Salamon who analyzed the delineations of volunteering in different countries and proved that "the English and American concept of "volunteering", French 'voluntariat', the Italian "voluntariato', the Swedish "frivillig verksamhet" and the German "ehrenamt", despite the same type of translation, have different origins and different cultural and political meanings" [11].

In the framework of our research, the term "volunteer", which has a Western origin, and the Slavonic term "volunteerism" have been used as interchangeable synonyms.

Voluntary activity of preschool children is understood as a voluntary, socially useful, gratuitous initiative aimed at helping others, social, cultural, environmental, sports oriented, carried out in a joint organized (unorganized) form under adults supervision, in the form of single short-term actions (regular systematic activity), which is of a subjective nature (volunteering as co-existence, leisure volunteering, family volunteering, online volunteering, etc.).

The pedagogical prerequisites for the formation of preschool volunteering for children are:

- reliance on humanistic theories of development;

- principle of openness of the preschool organization;

- creation of a close, safe, developing, aesthetic environment when organizing children's associations in accordance with children's interests,

- teachers' willing to support children's activity, independence and initiative,

- principle of social focus of education,

- educator participation in organisation of volunteer activities to stimulate the cognitive activity of children, support their self-esteem,

- reliance on the strengths of the personality, based on the age characteristics of the child, his needs, interests, the socio-cultural environment in which he is, and his relationship with this environment.

Individual - personal prerequisites are the innate need for self-actualization, humanistic needs for goodness, morality, benevolence and ways of their implementation.

The purpose of our study is to scientifically substantiate, develop and test the psychological and pedagogical conditions for the development of older preschool children's initiative on the basis of volunteer activities.

The complex of psychological and pedagogical conditions for the development of older preschool children's initiative on the basis of volunteer activities includes:

- a structural and functional model of the process of developing older preschool children's initiative by means of volunteer activity, represented by the stages of diagnostic goal-setting, organizational and content planning, design and implementation, reflection and correction;

- partial program, social and pedagogical, the value content of which ensures the process of developing the initiative of preschoolers in volunteering;

- technology for the development of initiative based on the integration of various types of volunteer activities;

- complex diagnostics.

Social volunteering (environmental activities: collection of waste paper, feeding birds, separate collection of garbage, planting flowers, bushes, sowing grass, etc.; helping children with special educational needs (for example, preparing theatrical attributes), participation of children in the "Letter to a Veteran" campaign, "Immortal regiment", etc.).

Cultural volunteering (rehearsing the roles for the upcoming matinee, help the teacher in the production of theatrical attributes of masks, posters, theater tickets, programs, assist in the distribution of programs and tickets, in decorating the stage for a theatrical performance, help the librarian to lay out books, participate in theatrical extras, flash-mobs, etc.) 
Environmental volunteering (preschoolers develop elementary ideas about the current environmental problems of their hometown, region, air pollution, garbage disposal, forest destruction, extinction of whole animal species, etc.).

Sports volunteering (preschoolers develop an idea of sports volunteering (inviting spectators to a sports event).

The main technologies for the development of initiative in older preschool children are:

1. Volunteering is a social technology for organizing the educational process in a preschool educational organization.

2. Social design as a technology for the development of the child's activity, initiative, independence and creativity.

3. The social situation for the involvement of older preschoolers in volunteer activities.

4. Technology of social and pedagogical support of preschoolers in the process of volunteering.

\section{Conclusion}

Thus, the socio-cultural context of the development of initiative in older preschool children on the basis of volunteering involves the organization of volunteer practices that act as a cultural attribute of social education and symbolize a situation of social success and the creation of a socio-cultural environment, when the development of initiative proceeded in the context of socialization and human culture; and also involves the organization of the child's interaction with society and the world of Culture.

The research results can be used in the preparation for lectures courses of disciplines "Theory and methods of preschool education", "Technologies of educational work in a preschool educational organization, in retraining and advanced training programs for teaching staff, when writing teaching aids for teaching and upbringing of older preschool children.

Promising directions for the development of the problem of this study can be: further study of the influence of volunteer activity on the development of initiative in preschoolers; studying the level of competence of teachers in the use of volunteering technology; development of forms and methods for the active involvement of parents of preschoolers in volunteer activities.

\section{Acknowledgments}

The reported study was funded by RFBR, project number No. 19-313-90065 dated 02.09.2019.

\section{References}

1. K.A. Abulkhanova-Slavskaya, Psychology and consciousness of personality (problems of methodology, theory and research of a real personality) (Moscow Psychological and Social Institute, Publishing House NPO "MODEK", Voronezh, 1999).

2. Y.L. Belyakova, Public administration, Electronic bulletin https://cyberleninka.ru/article/n/sotsiokulturnyy-podhod-etapy-formirovaniya-iossotsiokulturnyy-podhod-etapy-formirovaniya-i-osnovnye-imperativy

3. A.A. Verbitsky, O.G. Larionova, Personal and competence-based approaches in education. Integration problems: monograph (M, 2010 
4. S.V. Galman, Volunteering as a means of raising a child in Russia in the xx century: dissertation...candidate of pedagogical sciences (Novgorod State University named after Yaroslav the Wise, Veliky Novgorog, 2015)

5. A.I. Krupnov, Psychological problems of a holistic analysis of personality and its basic properties. Psychological and pedagogical problems of personality formation in the student's educational activity (RUDN, M., 1988)

6. N.I. Lapin, Russian Civilization: Ethnocultural and Spiritual Aspects: Ents. dictionary (Respublika, M., 2001)

7. A.S. Makarenko, Education of the citizen (Education, M., 1988)

8. A.V. Mudrik, Social pedagogy: textbook (Add. Ed. Center "Academy", Moscow, 2003)

9. P.D. Pavlenok, Social work methodology ("Dashkov and K", M., 2004)

10. Y.V. Parshina, Moral formation of an older teenager in volunteer activity: diss. Cand. ped Sciences (Voronezh, 2011)

11. M.V. Pevnaya, Volunteering as a social phenomenon: management approach: dissertation...Doctor of Social Sciences (Ural Federal University named after the first president of Russia B.N. Yeltsin, Yekaterinburg, 2016)

12. A.V. Svyatseva, S.B. Shukhardina, Pedagogical education in Russia 3, 88-93 (2016)

13. Yu.V. Alekseev, et al, Modern encyclopedia of social work (Publishing house of RSSU, Moscow, 2008)

14. D.N. Ushakov, Explanatory dictionary of the Russian language (State. in-t "Sov. encycl." OGIZ, M., 1935-1940)

15. Federal state educational standard of preschool education (Perspective, M., 2014)

16. K.N. Shapovalova, Teacher of the XXI century 1 https://cyberleninka.ru/article/n/osnovnye-podhody-k-rassmotreniyu-ponyatiyainitsiativnost-v-istoricheskom-aspekte

17. S.G. Shatskiy, Pedagogical essays (Pedagogika, M., 1964) 